\title{
The Development of Physics Teaching Materials Based On Local Wisdom To Improve Students' Critical Thinking Ability
}

\author{
Landiana Etni Laos ${ }^{1}$, Meti Tefu ${ }^{2}$ \\ STKIP SoE, Indonesia ${ }^{1,2}$ \\ landianalaos28@gmail.com ${ }^{1}$, metitefu@gmail.com²
}

Received: November $29^{\text {th }}, 2019$. Revised: May 22 ${ }^{\text {th }}, 2020$. Accepted: May $23^{\text {th }}, 2020$

\author{
Keywords : \\ Physics Teaching Material; \\ Local Wisdom; Critical \\ Thinking Skill
}

\begin{abstract}
$A$ research and development study had been conducted to evaluate the appropriateness of local wisdom based physics teaching material in order to increase students' critical thinking skill. This study was based on 4-D development model including Define, Design, Develop, and Disseminate. Data was gathered from 30 research participantsin SMK Kristen Fautmolo. Observation, interview, questionnaire and test were data collection techniques. Before applying the instruments in data field, validation was garnered from 4 physics experts with 3.75 total score in very good category which indicated the developed material's applicability in teaching and learning process. The result revealed that the local wisdom-based physics teaching material was effective to improve students' critical thinking skill with 0.80 of $\mathrm{N}$ gain score (high) and $89.91 \%$ of students' responses toward learning using the material. Therefore, it could be concluded that the developed local wisdom-based physics material was appropriate to be used in physics learning and could improve student's critical thinking skill.
\end{abstract}

\section{INTRODUCTION}

Education is a process of someone's or particular group's attitude and behaviour transformation in order to be maturated through teaching and training. This process can run smoothly, conducive, and interactively in teaching and learning process if it is implemented well and being ultimately supported by curriculum [1]. Primarily, the current 2013 curriculum which supports learning can make use of culture in which it is responsive toward the development of science, culture, technology and art that in result cultivates students' curiosity and skill to utilize them correctly [2].

Physics is a fundamental science as it functions as basic of science learning, materials structure, and their interaction in order to comprehend natural and human-made system. Based on the definition, physics concepts are important to be acquired but some studies reveal that secondary school students have difficulties in physics learning [3-4].

Physics learning in SMK Kristen Fautmolo was teacher-centered which caused students to mostly listen, copy, and memorize taught materials whereas in learning process, teacher emphasized more on 
knowledge and rarely related the concepts with learning media available in students' surroundings. This was found in the result of interview with physics teacher and observation during physics class in the school. $60 \%$ showed that during learning process, teacher was mainly active than students and acted as main source to problem solving which made students to lack in critical thinking ability in order to solve problems, lack of comprehension, and mastered the concepts. Besides, the applied teaching device was not related to the environment and traditions of the community. The consequence was low thinking ability to master concepts which made students less critical in solving problems. Hence, teaching materials which connected physics concepts and local wisdom were needed to help students understand concepts and enhance their critical thinking competence.

Upgrading learning effectiveness could be achieved by designing learning device, defining learning method, and using teaching relevant materials to ease students in expanding their critical thinking skill to grasp concepts. Critical thinking is a success learning indicator [5]. It was meant to explore clarity by questioning all aspects related with intended information in detail to gain truth from the information and draw objective conclusion [6]. Thinking cultivation is preffered to be done by education practitioners as it maximized thinking tendency to better direction.

As facilitators, teachers bore the demand to actively designing learning process in appealing fashion for their students. An alternative of these interesting designs was to develop local wisdom-based physics teaching material. It indicated that this design could link physics concepts with experiences students had. Local wisdom is life perceptionand science also varied life strategies realized in local community's activities to answer problems encountered while fulfilling their life necessitiess [7]. Local wisdom included everything that characterized a region in form of food, customs, dances, folks or traditional rites [8]. Local wisdom also take parts as the life guidance, science and various life strategies that are manifested in the activities of local communities to answer various problems needs in community members [9].

Efforts that teachers could do to improve students' inner understanding was to relate their daily experiences or concepts existed in their minds with learning contents being discussed. This point was in accordance with the proposition [10] that students who gained knowledge through direct experiences could improve their cognitive domain easier. Learning using ethno-science approach gave learners comprehension to appreciate nature and apply science in daily life [11]. Ethno-science is the activity of transforming natural science into scientific science [12]. This type of learning would provide relevance to students concerning learning they faced with real life events. This study aimed to develop local wisdom-based physics teaching material which could improve students critical thinking ability.

\section{METHOD}

This research was conducted using research and development method that utilized the 4D development model. This model consisted of 4 development stages including define, design, develop, and disseminate.

The first stage was define in which needs analysis, core competence and basic competence analysis, students and concepts analysis were undertaken sequentially to depict fundamental concepts in the developed teaching material which would be the teaching material design's principle (1st draft). The second was design stage that covered designing components of the local wisdom-based physics teaching material including local wisdom texts and pictures, followed by questions that practise learners' critical thinking skill. The third was develop phase which aimed to produce proper local wisdom-based physics teaching material theoretically ( $2 \mathrm{nd}$ draft). This phase comprised experts' analysis and validation. The first draft was then analyzed by 3 physics lecturers and a physics teacher to obtain feedbacks as consideration source to correct the draft into second draft which was ready for a trial. The last was disseminate stage conducted in SMK Kristen Fautmolo by implementing the local wisdom-based physics teaching material in physics class to identify the subjects' critical thinking skill. 
Data collection techniques were questionnaire and test whereas the instruments used to collect data were questionnaire for validation, multiple choice test items, and students' responses questionnaire toward the developed material. Data analysis technique for for the teaching material and questionnaire validity was pecentage technique to diagnoze the appropriateness of the applied teaching material and students' responses questionnaire. Students' critical thinking skills test items were analyzed using normality gain test [13].

\section{RESULTS AND DISCUSSIONS}

Local wisdom applied in this study was traditional sago processing from coryphaor gebang palmtree in South Middle Timor regency. The process was traditionally manual begun by cutting the trunk, crosscutting the trunk in particular size, separating sago pith from the trunk, slicing, draining under the sun or fogging during rain, graining, sieving, washing/soaking, dryingsago starch's sludge, and sago combustion. Among the phases, sago draining, sago starch's sludge draining, and sago combustion were selected and related to calor transfer material in order to produce local wisdom-based physics teaching material on heat transfer topic.

This study was done in three times meeting under thermal conduction, convection, and radiation topic. The relationship of sago processing local wisdom and physics concepts can be seen in Table 1 .

Table 1. The relationship of sago processing local wisdom and physics concepts

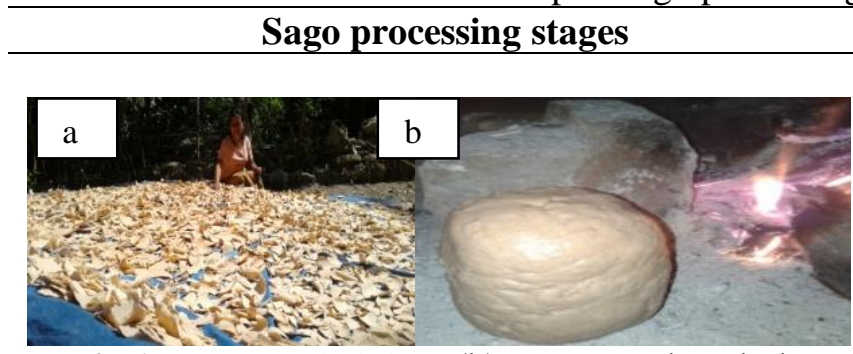

Fig 1. (a) Sago draining, (b) Sago starch's sludge draining

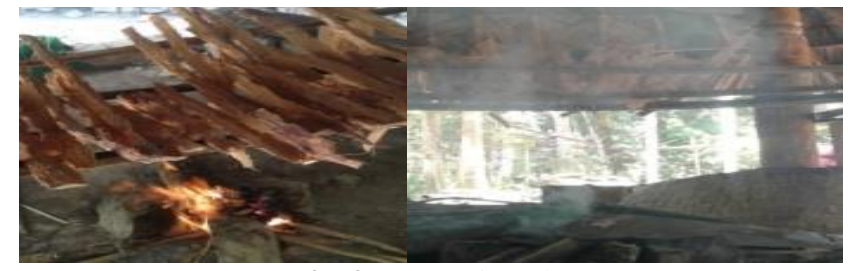

Fig 2. Sago fogging

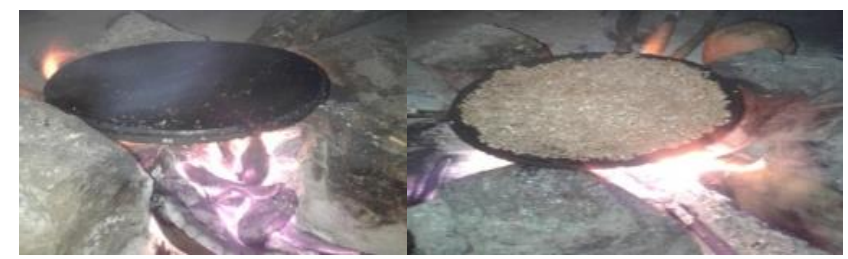

Fig 3 . Sago combustion process
In sago draining process under the sun and sago starch's sludge draining, thermal radiatonoccured.

Sago draining during rainy days was done with sei tradition in which sagos were laid on attic (pana) for fogging process. This fogging process indicated thermal convection.

The mixture of sago dough was poured into mold (lana) to be ignited. In this stage, thermal conduction happened. 
The Development of Physics Teaching Materials Based On Local Wisdom To Improve... Landiana Etni Laos, Meti Tefu

The appropriateness result of local wisdom-based physics teaching material and students' responses questionnaire.

Teaching material's validation result was presented in Table 2 and 3.

Table 2. Calculation of Teaching Material's Validation

\begin{tabular}{llcccccc}
\hline \multirow{2}{*}{ No } & \multirow{2}{*}{ Assessed Aspects } & \multicolumn{9}{c}{ Assessment Score } & & \multirow{2}{*}{ Average by Validator } & \multirow{2}{*}{ Average } & \multirow{2}{*}{ Criteria } \\
\cline { 3 - 6 } & $\mathbf{1}$ & $\mathbf{2}$ & $\mathbf{3}$ & $\mathbf{4}$ & & \\
\hline 1 & Material's appropriateness & 4,00 & 3,33 & 4,00 & 4,00 & 3,83 & Very Good \\
2 & Register & 4,00 & 3,50 & 3,50 & 3,50 & 3,62 & Very Good \\
3 & Concept's truth & 4,00 & 4,00 & 4,00 & 4,00 & 4,00 & Very Good \\
\hline
\end{tabular}

Table 3. Calculation of Validation Teaching Material's Construction

\begin{tabular}{lllllllll}
\hline \multirow{2}{*}{ No } & \multirow{2}{*}{ Assessed Aspects } & \multicolumn{4}{c}{ Assessment Score } & \multirow{2}{*}{ Average by Validator } & \multirow{2}{*}{ Average } & \multirow{2}{*}{ Criteria } \\
\cline { 3 - 6 } & & $\mathbf{1}$ & $\mathbf{2}$ & $\mathbf{3}$ & $\mathbf{4}$ & & \\
\hline \multirow{2}{*}{1} & $\begin{array}{l}\text { Teaching material's } \\
\text { components completeness }\end{array}$ & 3,87 & 3,50 & 3,62 & 3,75 & 3,68 & Very Good \\
2 & Register & 4,00 & 3,50 & 4,00 & 3,75 & 3,81 & Very Good \\
3 & Graph components & 3,00 & 4,00 & 4,00 & 3,33 & 3,58 & Good \\
\hline
\end{tabular}

The average score was 3.75 with very good criterion based on Table 2 and 3 so the teaching material could be used without revision. Thus, in could be concluded that the developed material was appropriate to be implemented in physics learning.

Students' responses questionnaire was constructed to identify their responses toward learning using local wisdom-based physics teaching material. The developed questionnaire was then validated by physics education practitioner and experts as presented in Table 4.

Table 4. Calculation of Students' Responses Questionnaire Validation

\begin{tabular}{|c|c|c|c|c|c|c|c|}
\hline \multirow[t]{2}{*}{ No } & \multirow[t]{2}{*}{ Assessed Aspects } & \multicolumn{4}{|c|}{$\begin{array}{c}\text { Assessment Score Average by } \\
\text { Validator }\end{array}$} & \multirow[t]{2}{*}{ Average } & \multirow[t]{2}{*}{ Criteria } \\
\hline & & 1 & 2 & 3 & 4 & & \\
\hline 1 & Instruction & 4,00 & 4,00 & 4,00 & 4,00 & 4,00 & Very Good \\
\hline 2 & $\begin{array}{l}\text { Learning elements } \\
\text { scope }\end{array}$ & 3,33 & 3,00 & 3,50 & 3,33 & 3,29 & Good \\
\hline 3 & Register & 4,00 & 4,00 & 4,00 & 4,00 & 4,00 & Very Good \\
\hline
\end{tabular}

Based on Table 4, the average score of all sapects was 3.76 with very good criteria. This implied that the students' responses questionnaire was applicable for the research.

Effectiveness Test of local wisdom-based physics teaching material

Students' critical thinking skill improvement was evaluated based on pretest and posttest result. Pretest was administered before learning process using local wisdom-based physics teaching material meanwhile posttest was given after learning process using local wisdom-based physics teaching material. The progress in their critical thinking skill was observed using $\mathrm{N}$-gain test formula. The result implied that whole students were effectively experienced improvement to think critically on heat transfer 
topic using local wisdom-based physics teaching material. This conclusion was drawn based on the improvement of 47.42 pretest score average into 89.67 posttest average score. $\mathrm{N}$-gain test result produced 0.80 score or high category. The posttest result indicated that $93.33 \%$ students completed their learning and $6.67 \%$ students did not complete their learning. The percentage of students' learning completeness could be achieved by applying local wisdom-based physics teaching material. The detailed calculation of students' critical thinking skill achievement level was presented in Figure 4.

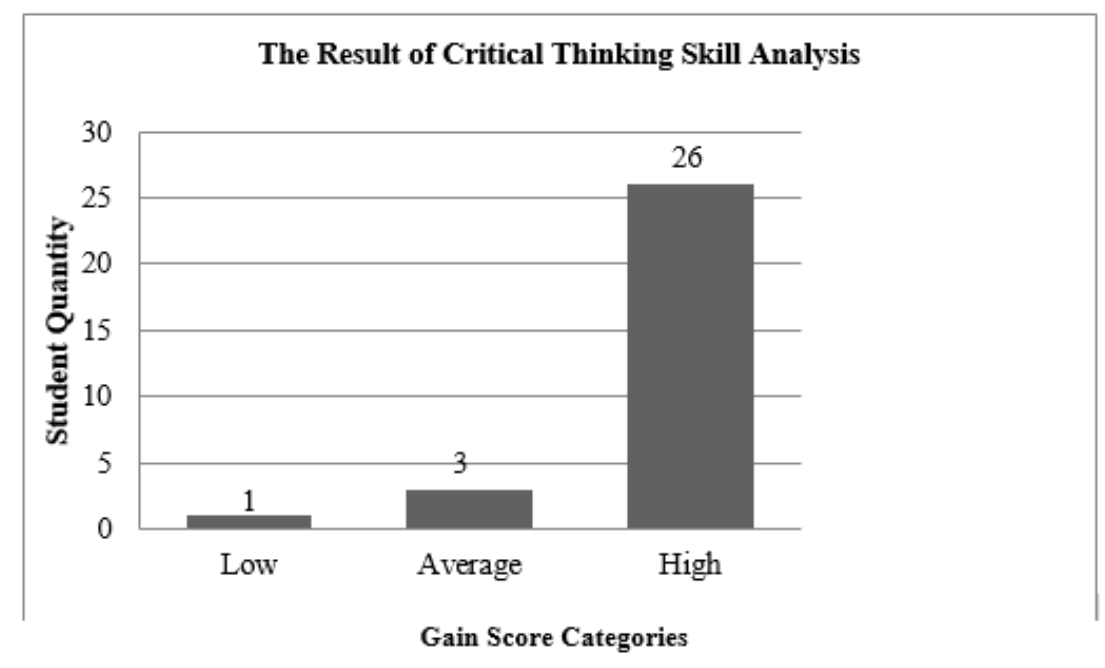

Fig 4. The Result of Critical Thinking Skill Analysis

Figure 4 displayed that 26 students accomplished high achievement category, 3 students on medium category, whereas 1 student was in low achievement category. Further, $t$-test formula was used to measure the significance of students' improvement to think critically using pretest and posttest result. The test was ran to know significant improvement of score between pretest and posttest in which the value of $t_{\text {count }} 15.19>t_{\text {table }} 1.70$ with 0.05 level of significance. The data revealed that $t_{\text {count }}$ was higher than $t_{\text {table }}$ therefore a conclusion could be drawn that there was significant improvement on students' score before and after applying local wisdom-based physics teaching material.

The calculation of each critical thinking skill indicator's achievement level in detail was shown in Figure 5.

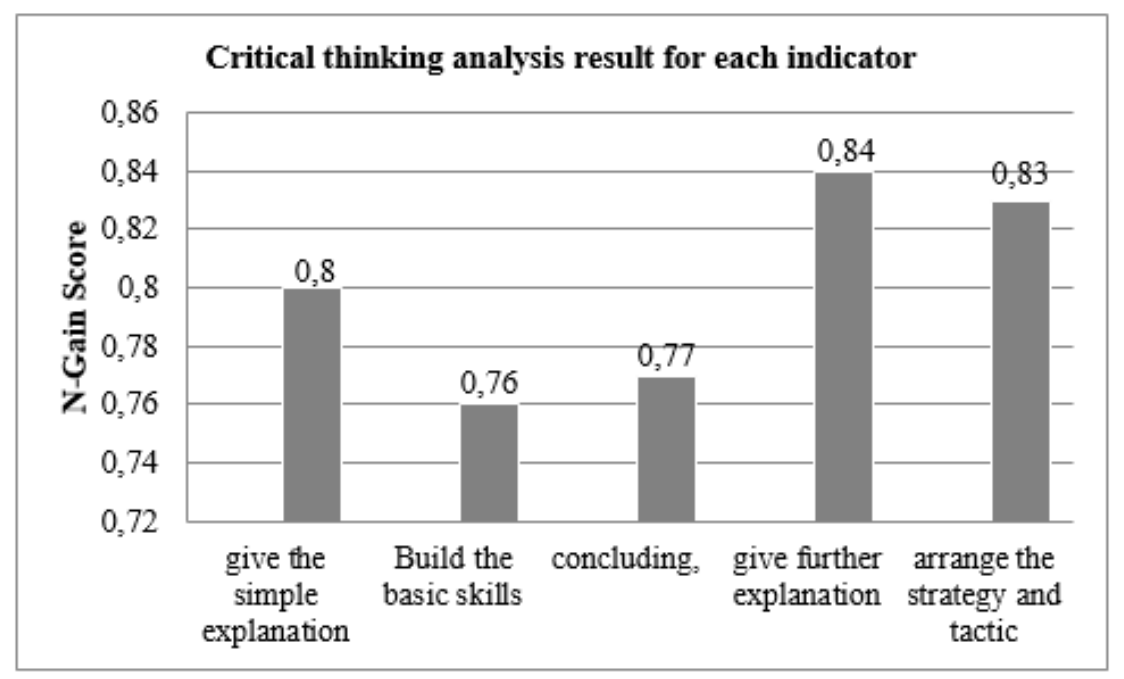

Fig 5. Analysis Result of Critical Thnking Skill Per Indicator 
Figure 5 depicted that $\mathrm{N}$-gain score of each indicator was in high category. Relying on the analysis result of students' improvement, it was found hat the developed teaching material could improve their critical thinking ability. Physics earning by making use of local wisdom was a learning experience that enabled learners to expand their cognitive, affective, and psychomotor competence. Students were offered opportunity to discover inherited concepts and customs surrounding them by themselves and develop critical attitude in solving problems.

Learning using local wisdom-based physics teaching material encouraged students to grasp concepts and enhance their critical thinking skill in problem solving, either in the context of heat transfer topic or in their daily lives based on their local tradition. This point was in line with research result [10] and [14] that ethno-science based learning could increase students' cognitive and critical thinking ability. Local custom oriented learning could also improve students' critical thinking skill [15]. The developed teaching material was local wisdom based which meant that the teaching material did not merely present the information of heat transfer from its scientific context but also relate the theory with their cultural comprehension, in this case traditional sago processing procedure. This idea was supported by [16] that local wisdom oriented learning involved students and their life traditions actually gave more contextual impression since it was directly connected with their custom and students' personal experiences. In the developed material, there were reasoning, observing, questioning, evaluating comprehension and reviewing activities with the purpose of improving students' critical thinking skill.

Analysis Result of Students' Responses toward Local Wisdom-Based Physics Teaching Material The detailed questionnaire's analysis result of the developed material was presented in Table 5.

Tabel 5. Data Result of Students' Responses

\begin{tabular}{cccccccc}
\hline No & $\begin{array}{c}\text { Student's } \\
\text { Code }\end{array}$ & $\begin{array}{c}\text { Percentage } \\
(\mathbf{\%})\end{array}$ & Predicate & No & $\begin{array}{c}\text { Student's } \\
\text { Code }\end{array}$ & $\begin{array}{c}\text { Percentage } \\
(\mathbf{\%})\end{array}$ & Predicate \\
\hline 1. & St1 & 82,50 & Very Positive & 16. & St16 & 77,50 & Positive \\
2. & St2 & 92,50 & Very Positive & 17. & St17 & 82,50 & Very Positive \\
3. & St3 & 72,50 & Positive & 18. & St18 & 90,00 & Very Positive \\
4. & St4 & 90,00 & Very Positive & 19. & St19 & 95,00 & Very Positive \\
5. & St5 & 75,00 & Positive & 20. & St20 & 77,50 & Positive \\
6. & St6 & 92,50 & Very Positive & 21. & St21 & 100,00 & Very Positive \\
7. & St7 & 87,50 & Very Positive & 22. & St22 & 92,50 & Very Positive \\
8. & St8 & 70,00 & Positive & 23. & St23 & 72,50 & Positive \\
9. & St9 & 82,50 & Very Positive & 24. & St24 & 92,50 & Very Positive \\
10. & St10 & 92,50 & Very Positive & 25. & St25 & 80,00 & Very Positive \\
11. & St11 & 77,50 & Positif & 26. & St26 & 57,50 & Quite Positive \\
12. & St12 & 75,00 & Positive & 27. & St27 & 92,50 & Very Positive \\
13. & St13 & 92,50 & Very Positive & 28. & St28 & 67,50 & Positive \\
14. & St14 & 80,00 & Very Positive & 29. & St29 & 95,00 & Very Positive \\
15. & St15 & 100,00 & Very Positive & 30. & St30 & 82,50 & Very Positive \\
\hline \multicolumn{7}{c}{$\mathbf{8 9 , 9 1 \%}$} \\
\hline
\end{tabular}

Based on Table 5, it was found that the total average of students' responses percentage was $89.91 \%$. percentega of students who gave very positive response were $66.67 \%$, positive $30 \%$ and quite positive $3.33 \%$. This result also marked that the learning process provided students with positive impact in learning activity, their enthusiasm to accept each problem, their effort to find problem solution through discussion, and actively asking the teacher. These were in accordance with research result [17] that local wisdom-based science handout development gained positive response from the students.

Their perseverance and motivation to learn were implied by their effective learning time management and learning concentration. There were several possibilities underlining students' attraction toward the developed material, among each other (1) examples of an event and its process in daily life that were 
related to the material, (2) systematic arrangement of sub-topics that eased students to read and comprehend material. Consequently, it could be summarized that the developed local wisdom-based physics teaching material was effective to be implemented in learning.

\section{CONCLUSION AND SUGGESTION}

Based on the result of this study, a it was concluded that the developed local wisdom-based physics teaching material on heat transfer topic was valid with very good category which made it appropriate to be applied in learning process as it could improve students' critical thinking skill with $0.80 \mathrm{~N}$-gain score (high) and $89.91 \%$ of students' response toward the developed material. It was recommended for further research to develop local wisdom-based physics teaching material on other topics to engage students in active learning.

\section{ACKNOWLEDGMENTS}

The researchers woluld like to express their sincere gratitude to Physics Education Program of STKIP SoE for sparing time and opportunity to the researcher to conduct this research, and Kemenristek Dikti for the funding aid to ensure the flow of this research.

\section{REFERENCES}

[1] Sudarmin, S., \& Samini, S. (2015). Efektivitas penggunaan modul terintegrasi etnosains dalam pembelajaran berbasis masalah untuk meningkatkan literasi sains siswa. Unnes Science Education Journal, 4(3).

[2] Kemendikbud. (2013). Peraturan Menteri Pendidikan Dan Kebudayaan Nomor 81A Tahun 2013 Tentang Pedoman Implementasi Kurikulum 2013. Jakarta: Kemendikbud.

[3] Veloo, A., Nor, R., \& Khalid, R. (2015). Attitude towards physics and additional mathematics achievement towards physics achievement. International Education Studies, 8(3): 35-43.

[4] Ekici, E. (2016). "Why Do I Slog through the Physics?" Understanding High School Students' Difficulties in Learning Physics. Journal of Education and Practice, 7(7): 95-107.

[5] York, T. T., Gibson, C., \& Rankin, S. (2015). Defining and measuring academic success. Practical Assessment, Research, and Evaluation, 20(5): 1-36.

[6] Fatimah, N., Gunawan, G., \& Wahyudi, W. (2017). Pembelajaran Berbasis Masalah Dengan Strategi Konflik Kognitif Terhadap Penguasaan Konsep Dan Kemampuan Berpikir Kritis Fisika Siswa Kelas XI SMKN 1 Lingsar Tahun Pelajaran 2015/2016. Jurnal Pendidikan Fisika dan Teknologi, 2(4): 183-190.

[7] Hidayanto, F. (2016). Pengembangan Modul Fisika SMA Berbasis Kearifan Lokal Untuk Mengoptimalkan Karakter Peserta Didik (Doctoral dissertation, Fisika/FKIP).

[8] Maknun, J. (2017). Konsep Sains dan Teknologi pada Masyarakat Tradisional di Provinsi Jawa Barat, Indonesia. MIMBAR PENDIDIKAN, 2(2).

[9] Fajarini, U. (2014). Peranan kearifan lokal dalam pendidikan karakter. SOSIO-DIDAKTIKA: Social Science Education Journal, 1(2): 123-130.

[10] Arfianawati, S., Sudarmin, M., \& Sumarni, W. (2016). Model pembelajaran kimia berbasis etnosains untuk meningkatkan kemampuan berpikir kritis siswa. Jurnal Pengajaran MIPA, 21(1): 46-51.

[11] Kartimi, K. (2014). Implementation of Biology Learning Based On Local Science Culture to Improvement of Senior High School Students Learning Outcome In Cirebon District and Kuningan District. Scientiae Educatia: Jurnal Pendidikan Sains, 3(2): 1-10. 
[12] Rahayu, W. E., \& Sudarmin, S. (2015). Pengembangan modul IPA terpadu berbasis etnosains tema energi dalam kehidupan untuk menanamkan jiwa konservasi siswa. Unnes Science Education Journal, 4(2).

[13] Sundayana, R. H. (2014). Statistika Penelitian Pendidikan. Bandung: Alfabeta

[14] Dewi, N. P. S. R., Wibawa, I. M. C., \& Devi, N. L. P. L. (2017). Kemampuan berpikir kritis dan keterampilan proses dalam pembelajaran siklus belajar 7e berbasis kearifan lokal. JPI (Jurnal Pendidikan Indonesia), 6(1): 125-133.

[15] Suputra, W., Sedanayasa, G., \& Dibia, I. K. (2013). Pengaruh Model GI (Group Investigation) Berorientasi Kearifan Lokal Terhadap Kemampuan Berpikir Kritis SD Negeri Di Desa Sinabun. MIMBAR PGSD Undiksha, 1(1).

[16] Maaruf, Z., Yassin, R. M., \& Yuliani, E. (2015). Pengembangan Modul Pembelajaran Fisika SMA Berbasis Kearifan Lokal untuk Meningkatkan Hasil Belajar Siswa.

[17] Safitri, A. N., Subiki, S., \& Wahyuni, S. (2018). Pengembangan modul IPA berbasis kearifan lokal kopi pada pokok bahasan usaha dan energi di SMP. Jurnal Pembelajaran Fisika, 7(1): 22-29. 